\title{
Perspectives of Spoken Grammar in Case Government
}

\author{
Olga Korobova, Larissa Generalowa, and Victoria Yanina \\ Volgograd State University, 400062, Universitetskiy av., Volgograd, Russia
}

\begin{abstract}
This paper deals with analysing the case government as a grammar category and explaining the contradictions in its interpretation with the main postulates of cognitive linguistics. The main idea of the paper is that grammar is considered to be a by-product of the language use when reality reflected in language consciousness finds its way in language grammaticalisation. It is suggested that case and prepositional and case structures are not connected with concrete verbs, but they express semantic arguments at the level of sentence. As a result, the case government is considered as forms of realization of semantic arguments of the significative structure. Its choice is caused by the use of the language in social interaction by mental modelling the reality.
\end{abstract}

The new direction which has arisen in the middle of the last century in linguistics defines all modern linguistic science in many respects today. Indisputable achievements and advantages of cognitive linguistics have allowed analysing significant divergences in traditional linguistics and interpreting its conceptual issues and a conceptual framework in a new way.

One of the main postulates of cognitive linguistics is the fact that all languages are based on perception of the real world. At the same time, there is a close interrelation between language and thinking, they influence each other and form the realized experience. Cognitive processes of the environment, as well as processes of thinking, are controlled by cerebral hemispheres, and can be treated by means of various psycholinguistic categories [23].

Everything that the man knows about the world and similar, he knows in the form of concepts and categories. Our initial acquaintance with extra language reality happens by means of classification as a form of reflection of the world in thinking when significant signs of concrete objects and images are generalized. Further in our consciousness there is certain "refraction" of reality representing conceptualization process, the essence of which consists in transferring of cognizable objects to a mental mode peculiar to the person. Conceptual categories function in consciousness as the points of support giving the chance of adequate interpretation of reality [30].

Thanks to our consciousness, we can correlate acquired knowledge of the world ontology with certain conceptual categories, which proves the creative nature of our thinking.

The last achievements in the field of neurogenesis have convincingly proved that the explication of the language system of knowledge is possible on the basis of the general cognitive signs, and the language semantic structure represents a conceptual framework which finds the manifestation in the structure of a concrete language [15].

Having the uniform mental nature, conceptual structures differ in the way of the explication that finds expression in various significative structures. We understand conceptual structures which correspond to a certain form of representation in a concrete language as significative structures. Significative values are created on the basis of conceptual structures thanks to the processes of language verbalization [29].

Thus, language units are designed to call a reality fragment, reflecting our ideas of it, and at the same time point to how this fragment is thought, defining the place of this fragment in the system of the relations in which our consciousness reflects surrounding reality. Such approach to consideration of language gives the chance to rethink many purely structural grammatical phenomena which can't be subject to explanation. Such syntactic structures are, as a rule, the forms of case government which have a wide scope of application in German.

The concept of case government has received detailed lighting in the works of many famous linguists [12, 16, $17,19,20,24,26,27,27,33,34]$; however the analysis of literature on this subject allows one to allocate three main shortcomings of interpretation of this phenomenon. First, this abundance of definitions, which receives a concept of government in the works of different authors - versatile and often mutually excluding definitions, reduced. However, a two-direction approach to a case government is traditional where government is interpreted as a type of the subordinative communication which syntactically realizes compatibility of a word, and the verb centric theory of the sentence in which government is considered as one of the ways of realization of syntactic valency of the verb. Secondly, case government, regardless of the

*Corresponding author: dephil@yandex.ru 
approach to consideration of this phenomenon, is always treated as semantic unmotivated phenomenon functioning in the sphere of syntax and morphology that causes interpretation of case government forms as the stiffened syntactic constructions which do not have variants and can't be modified [18].

However, as practice shows, the language represents the living organism inclined to continuous changes that it is caused as it was mentioned above earlier, by the fact that structures of perception of the surrounding reality by the human consciousness are the cornerstone of the language. Social changes in society define changes in consciousness of the man and that is reflected in the language. First of all, these transformations are visible in colloquial language both at the level of lexicon, and at the level of grammar which, in our opinion, should be understood not as the abstract system of rules, but as a technique of orientation to the models of the use of language forms and their variants used in everyday language [1, 3, 14]. After Martin Haspelmath we will consider grammar as a by-product of the language use in the course of social interaction [13]. At the heart of such approach lies the idea that language categories as reflection of cogitative categories of perception of reality arise in the course of their use in the speech when native speakers use similar language structures for the solution of the similar language tasks. The reality reflected in the language consciousness can have several ways of explication in the language, but cyclic character of language grammaticalisation, that is language structuration by categories, defines the prevailing nature of the use of this or that form at a certain stage of the language development [32].

In our opinion such approach allows to explain contradictions in the interpretation of the case government as in fact, there is no need to allocate such grammatical phenomenon. Traditionally it is considered that the case and the prepositional and case forms by means of which there is an explication of participants of situation at the level of the sentence depend on the verb and are a part of syntactic structure. However the language facts convince us otherwise. So, the same case and prepositional and case forms express the same relations with different verbs regularly. For example, such semantic argument of significative structure as objective which is thought as the certain object which is exposed to a certain influence is regularly expressed by the absolute accusative case regardless of the lexical meaning of the verb.

Such influence can be described by the verbs like:

öffnen, aufmachen, zumachen, verschließen:

Sie öffnete die Tür. [4:42]

speaker_137 Oder eine Party, wie die geschildert wird, eine Party wird geschildert, Stimmengewirr kam auf, als man die Tür aufmachte. / Das Literarische Quartett vom 25. Februar 2000/ [8]

Er hatte die Flasche zugemacht. [21:321]

Or by the verbs describing change of the object location: zerren, rücken, sich rücken, reißen:

Er rückte sich die Mütze in die Stirn. [30:31]

speaker_157 Da schreibt er : " Hitler verwüstet Polen, die Mutter riss alle Blumen aus ihrem Garten und pflanzte Gemüse an . / Das Literarische Quartett vom 18. August 2000/ [8]

Vor zwei Wochen hat ein Krokodil ein kleines ZuluMädchen in die Tiefe gezerrt, das beim Spielen dem Ufer zu nahe kam. [21:126] object:

Or by the verbs describing complete change of the

ändern, abändern, verzehren, zehren:

Das ändert die Sache. [9:237]

Die Krankheit verzehrte ihre Schönheit. [7:248]

__speaker_139 Dann sind da Juden, die auch ihren Ursprung schon gar nicht mehr benennen dürfen , die ihren Namen ändern ./Das Literarische Quartett vom 22. Juni 2001/ [8]

We observe a similar situation with the group of verbs describing an impact on an emotional and mental or physiological state of the object:

angreifen, bewirken, hervorrufen, beeinflussen, überraschen, beeindrucken, einschüchtern, täuschen, abschrecken, beirren, besänftigen, betrüben, demütigen, deprimieren, enttäuschen, entzücken, erheitern, erhellen, erschüttern, ermüden:

\section{Dieses Leiden hat seinen Tod bewirkt. [10:193]}

Das greift die Nerven an. [4:67]

__speaker_135_speaker__135 Ja, das ist nicht die schlechteste Literatur, die Angst hervorruft . I Das Literarische Quartett vom 26. August 1999/ [8]

And this happens also with the verbs describing performance of the action directed to the object possession:

suchen, angeln, jagen, greifen, langen, schnappen, tasten, ringen, fahnden, graben, bohren, sich bücken, haschen, abstreichen, stochern, buddeln, abrennen, abstöbern, abstreichen, absuchen, abgrasen, abklappern, ausblicken, ausschauen, ausgucken and a phrase einen Griff tun:

Uns fehlt der richtige Standpunkt, wir müßten ihn suchen, um im Leben Standfestigkeit beweisen zu können. [24:227]

Wir haben heute noch nichts gejagt. [5:34]

__speaker_26 Aber die Union pflegt die fatale Neigung, immer dann Politik zu Lasten von 
Asylbewerbern und Ausländern zu inszenieren, wenn sie ihre Identität sucht . / Mestmacher, Christoph / Rosenkranz, Gerd, "Nicht einfach davonstehlen", in: Der Spiegel 05.03.2001, S. 26, 28 u. 30/ [8]

Thus, the subject of the action directed to it is usually made out in German by the nonprepositional accusative case. At the same time we can observe some signs of the influence of the language use in the analysis of forms of an argument explication in informal conversation. So, for example, the verb sich erinnern which is traditionally operating prepositional and case structure of an Akk has colloquial erinnern Akk option:

Ich kann leider den Namen dessen nicht erinnern, der das gesagt hat, er sprach wirklich akzentfrei, war ein Türke, aber in Deutschland aufgewachsen. /Das Literarische Quartett vom 15. Dezember 2000 __speaker_135/[8]

_speaker_137 Ich erinnere das auch deshalb, weil die Liebesfluchten mit dieser Art des Erzählens wieder sehr viel zu tun haben. /Das Literarische Quartett vom 25. Februar 2000/ [8]

It means that the influence of cogitative structures forces out the relevant syntactic structures, replacing them by more adequate. The matter is that traditionally a thought or a speech object is treated as a semantic argument deliberative that in our opinion can't correspond to the truth as the ontologic signs of the reflected situation aren't considered at the deep level of semantics. Respectively, here we can speak only about objective which is expressed by absolute accusative case. As for the $A k k$ form, here we deal with the orientation of action which is expressed by an preposition:

speaker_135 So erinnere ich mich an das Stück, ganz interessant, dass auch von dieser Seite her der Stoff verwendet wurde . / Das Literarische Quartett vom 4. Mai $2001 /[8]$

Classical deliberative represents the mediated object included in an action, process or state and this mediation is fixed in language über Akk pretext.

Such deliberative is expressed when reflecting the verbs:

denken, nachdenken, nachgrübeln, grübeln, nachsinnen, sinnen:

Er dachte über die Worte des Lehrers nach. [2:331]

Darüber habe ich schon oft vergeblich nachgegrübelt. [7:262]

speaker_663_speaker_663 Ich würde mir gern den Ärger ersparen, darüber nachzugrübeln, was meine Fans in mir und meinen Liedern sehen . / o.A., "So ist das Leben - es passiert", in: Der Spiegel 13.10.1997, S. $245-$ 246, 248-249 u. 252/ [8]

In describing expression of emotions concerning something, the following verbs are used: klagen, sich beklagen, sich belustigen, fluchen, sich entrüsten, aufhalten, sich empören, spotten, jammern, schimpfen, wettern, sich amüsieren:

Mein Vater, eine rheinische Frohnatur, war immer zu lustigen Streichen aufgelegt, über die wir gerne lachten. [7:93]

speaker_433 Die Touristen klagen über Baulärm, häufig über - unfreundlichen Service, verdreckte Hotelzimmer, ungepflegte Bettwäsche . / Bölke, Peter / Deckstein, Dinah, "Wir bohren nach", in: Der Spiegel 29.05.2000, S. 103 u. 106/ [8]

Die witzige Betty scherzte gerne über den Status ihres Films. [7:69]

In explicating a situation of obtaining information and reporting of information by the verbs:

sich austun, berichten, erzählen, schreiben, erklären, verraten, referieren, sprechen, sich befragen, verlauten, debattieren, überzeugen, sagen, aussagen, reden, bemerken, sich äußern, sich unterhalten, sich auslassen, urteilen, sich aussprechen:

speaker_ $135 \ldots$...Also, Frau Radisch, jetzt können Sie sprechen über Peters, so viel Sie wollen. / Das Literarische Quartett vom 14. Dezember 2001/ [8]

Sie hatten nichts über seine Identität von damals ausgesagt. [6:115]

In expressing an information request by the verbs, the following is used:

fragen, nachfragen, ausfragen, forschen, befragen, sich erkundigen, ausforschen, ausholen, aushorchen:

An Friedrich Heinrich Jacobi, der ihn darüber befragt hatte, schrieb er am 29. Juni 1795. [21:351]

\section{Er hat mich über meine Absichten ausgefragt. [7:14]}

Conceptualizing the process of feelings developing is described by such verbs as:

sich täuschen, sich betrüben, erschrecken, sich trösten:

Er erschrack über die mücklichen Folgen seiner Tat. [21:188]

Täuschen wir uns nicht über den Ernst der Lage. [6:319]

In reflecting the condition of having feelings to an object, the folowing verbs are used:

sich ärgern, sich aufregen, sich erregen, erschrecken, erstaunen, sich bekümmern, sich grämen, trauern, sich beunruhigen, sich wundern, sich freuen:

Er ärgert sich immer über jede Kleinigkeit. [11:90]

Wenn man sich über so was nicht aufregen kann, dann gibt es überhaupt nichts mehr, worüber man sich 
aufregen kann. / Regener, Sven: Herr Lehmann, Frankfurt am Main: Eichborn AG 2006 [2001], S. 249/ [8]

Sie wundern sich über die vielen Baumaterialien, die hier herum liegen. [6:228]

In such cases, the influence of the language use on the arrangement of semantic arguments in the speech is, as a rule, observed. So, the prepositional and case structure of über Akk has gradually forced out the traditional an Akk form at the verb denken and has already become a norm of speech and language:

speaker 523 Sogar noch kulturell $\neg$ was immer

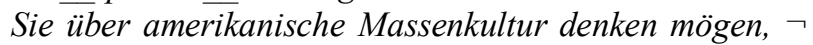
wirken die USA ungemein attraktiv . / Hoyng, Hans / Simons, Stefan, "Bush ist kein Dummkopf", in: Der Spiegel 01.01.2001, S. 104-105/ [8]

Thus, certain prepositional and case forms regularly express the same semantic relations as a part of similar significative structures regardless of the lexical meaning of the verb. Moreover, the same verb can express different relations which are made out by different syntactic structures as, for example, the verb sich freuen:

speaker_555 Die freuen sich schon auf ihren ersten großen internationalen Auftritt ./ o.A., "BungeeSpringen ohne Seil", in: Der Spiegel 03.11.1997, S. 207208/ [8]

speaker 379 speaker 379 Der Senat weiß, dass der überwiegende Teil der Bevölkerung hinter ihm steht, und freut sich über die Unterstützung . I o.A., Gespräch über die Aufgaben des neuen Hamburger Senats, 31.03.1933/ [8]

So, within the offered research we have come to the following conclusions:

In modern linguistics there is a need for detailed revision of case government as a separate grammatical category. Our hypothesis is spoken well by the fact that expressing semantic arguments case and prepositional and case structures aren't connected with concrete verbs and can't submit to them and also aren't the ways of realization of syntactic valency of concrete verbs. We suggest considering this phenomenon as forms and variants of realization of semantic arguments of significative structure which choice is caused by the use of the language in the course of social interaction and the way of mental modeling of a concrete situation of extra extralinguistic reality.

\section{References}

1. A. Deppermann, Gr. u. Int., 43-65 (2006)

2. A. und B. Pease, Warum Männer nicht zuhören und Frauen schlecht einparken. (Ullstein, 2001)

3. Á. Vilmos, M. Hennig, R. Germ. Ling. 269, 335 (2006)
4. C. Link, Schattenspiel (München,1991)

5. C. Link, Sturmzeit (München, 1991)

6. C. Link, Wilde Lupinen (München, 1991)

7. Das Hollywood Archiv (Wien, 2000)

8. Digitales Wörterbuch der deutschen Sprache. Korpora: https://www.dwds.de/r

9. G. Fink, Traumdeutung (München, 1990)

10. H. Fallada, Junger Herr - ganz groß (Berlin, 1997)

11. J. Evermann, Das Lexikon der deutschen Soaps (Berlin, 2000 )

12. K. Zommerfeldt, For. Lang. at Sch. 1, 24-31 (1975)

13. M. Haspelmath, S. T. Wiss. 262-286 (2002)

14. M. Hennig, K. U. Pr. 348 (2006)

15. M. Schwarz, Kognitive Semantiktheorie und neuropsychologische Realitaet: repräsentationale und prozedurale Aspekte der semantischen Kompetenz. (Tübingen: Niemeyer, 1992)

16. M. Stepanova, G. Helbig, Parts of speech and problem of valency in modern German language. 342 (1978)

17. N. Shwedova, Russ. Lang. En., 83-105 (1975)

18. O. Dementyeva, V. Kurakov. V. St. U. 2, 97-103 (2003-2004)

19. O. Moskalskaya, Problems of system describing of syntax 2, 173 (1981)

20. O. Sirotinina, Lectures on syntax of Russian language (Moscow, 1980)

21. R. Safranski, Friedrich Schiller 371 (2004)

22. S. Günter, H. Sylvio, Schatzsucher (Bechtermünz Verlag, 2000)

23. S. Katsnelson, Lang of S1. Cult., 864 (2001)

24. S. Kibardina, Valency and semantics of German verbs 67 (1983)

25. T. Mann, Der Zauberberg. (Frankfurt-am-M., 1980)

26. V. Beloshapkova, Syntax. Mod. Russ. Lang 481-492 (1981)

27. V. Beloussov, I. Kovtunova, I. Krutchinina, Inst. Of Russ. Lang. 2, 639 (1990)

28. V. Bondtsio, For. Lang. at Sch. 5, 15-23 (1977)

29. V. Demyankov, Ling. 4, 17-31 (1994)

30. V. Kurakov, Ax. Ling. : Pr. Of Ling Consc., 22-29 (2003)

31. W. Gabel, Fix und fertig (Weinheim, 1998)

32. W. Imo, Spr.-Lit.-K.-K.-Did. 4, 261-284 (2009)

33. Y. Apresyan, Typ. Of Lang. a. Asp. of Gr., 17-21 (2007)

34. Y. Skoblikova, Agreement and government in Russian (1971) 